\title{
Pesticide use data for emission modelling: A case study on the Upper Citarum River Basin
}

\author{
Rosetyati R. Utami ${ }^{1,2, *}$, Gertjan W. Geerling ${ }^{3,4}$, Indah R.S. Salami ${ }^{1}$, Suprihanto \\ Notodarmojo $^{1}$, and Ad M.J. Ragas ${ }^{4,5}$ \\ ${ }^{1}$ Department of Environmental Engineering, Faculty of Civil and Environmental Engineering, \\ Institut Teknologi Bandung, Jl. Ganesha no. 10, Bandung 40132, Indonesia \\ 2 Institute for Science in Society, Faculty of Science, Radboud University, P.O. Box 9010, 6500 GL \\ Nijmegen, The Netherlands \\ ${ }^{3}$ Deltares, P.O. Box 177, 2600 MH Delft, The Netherlands \\ ${ }^{4}$ Institute for Water and Wetland Research, Department of Environmental Science, Faculty of \\ Science, Radboud University, P.O. Box 9010, 6500 GL Nijmegen, The Netherlands \\ ${ }^{5}$ Department of Environmental Sciences, Faculty of Science, Open University, 6419 AT Heerlen, \\ The Netherlands
}

\begin{abstract}
Information on pesticide use types and pesticide use are needed to estimate pesticide emissions in the surface water. Unfortunately, these data is either limited or even non-exist in most low- and middleincome country like Indonesia. This problem is considered a missing link in the water monitoring system, especially in the emission estimation model approach. To overcome that problem, a questionnaire survey about pesticide use by the farmer was conducted in the Upper Citarum River Basin (UCRB) agriculture area. The survey result showed that 31 pesticides were used by farmers in UCRB, with pesticide type of insecticide $(58 \%)$ as the most used by the farmers. Overall, Profenofos and Mancozeb had the widest used in UCRB. For rice crops, as the broadest agriculture area in UCRB, Carbamates and Pyrethroid-based insecticides such as Carbofuran and Deltamethrin were the most frequently mentioned pesticides of the farmers. The variation in application frequency influenced the amount of pesticide use for each crop. In general, the frequency of pesticide application for vegetables was higher (from 7-10 times/ month) than rice and tubers ( $\leq 1$ time/ month).
\end{abstract}

\section{Introduction}

Continuing population growth drives the increasing demand for food. To fulfill the increase in demand, agricultural activities are intensified. One method of agricultural intensification is pesticides to protect crops from pests or weeds and improve the productivity and quality of crop yields $[1,2,3,4]$. The amount of pesticides used keeps increasing significantly in developing countries $[5,6]$. The massive usage of pesticides causes adverse effects on human health and the environment, especially in surface water pollution $[2,7,8]$.

\footnotetext{
* Corresponding author: rosetyatiretno@gmail.com
} 
Surface water contamination due to pesticide use is a high priority environmental issue and a cause of primary global concern [9]. A significant source of surface water pesticide contamination is through agricultural runoff $[10,11]$. It is essential to know the surface water concentrations of pesticides for estimating risks for ecology and human health, setting priorities, and regulation $[12,13]$. Modeling the emissions, fate, and transport is one tool to obtain pesticide concentration in water. An emission model is more cost- and timeefficient than direct measurements in the stream and can be used to assess management options [14]. One crucial variable in the emission estimation model is the pesticide use data, i.e., the amounts used and application frequency per crop type. Unfortunately, this kind of data is not centrally available or difficult to obtain in many low- and middle-income countries like Indonesia. It's generally only available in other countries through expensive market research or at the national scale, which may not be representative of localized conditions [15].

This study aims to provide the pattern and pesticides used for different crops as input data for an emission estimation model. This paper reports the results of a questionnaire survey on pesticide use by farmers in the Upper Citarum River Basin (UCRB) as a case study.

\section{Method}

A questionnaire was designed to gain information about the amount and types of pesticides used by farmers in the UCRB agricultural area. The questions focused on 1) general information about the respondents (name, gender, age, address); 2) Farmland information such as farmland size \& location, type of crops, harvesting \& planting period, pre-harvest interval; 3) pesticide application data such as brands, type, pesticide (active ingredient; a.i.), quantity and frequency of application and pesticides purchased.

A number of 174 farmers were surveyed in eight districts at different elevations along the UCRB, i.e., Lembang, Cihampelas, Solokan Jeruk, Ciparay, Majalaya, Pacet, Pangalengan, and Ciwidey. For every location, two interviewers were accompanied by a local guide known in the local community, and respondents were selected using a random walk and quota sampling method.

The surveys were conducted between January and March 2016 by personal visits to the farmers in the daytime. The interview was face-to-face, participation was entirely voluntary, and farmers were free to deny us information without justifying. In practice, no farmer objected, and only complete questionnaires were inputted in the final dataset.

\section{Results and discussion}

\subsection{Types of pesticides}

The Questionnaire survey results showed that 31 types of pesticides were used by 156 farmers $(89.7 \%)$. The remaining 18 did not use pesticides. The pesticides in use consisted of 5 pesticide groups: insecticide (i.e., Abamectin, Alpha-cypermethrin, Beta-cyfluthrin, Carbofuran, Chlorantraniliprole, Chlorfenapyr, Chlorpyrifos, Cypermethrin, Deltamethrin, Dimehypo, Emamectin Benzoate, Endosulfan, Imidacloprid, Lufenuron, Methomyl, MIPC, Profenofos, Spinetoram); fungicide (Azoxystrobin, Chlorothalonil, Difenoconazole, Mancozeb, Maneb, Mefenoxam, Metiram, Propineb); plant growth regulator (PGR) (2Nitrophenol Sodium Salt \& 4-Nitrophenol Sodium Salt); rodenticide (Brodifacoum); and herbicide (Metsulfuron-methyl \& Paraquat dichloride). The proportion of pesticide types in UCRB is shown in Fig. 1. 


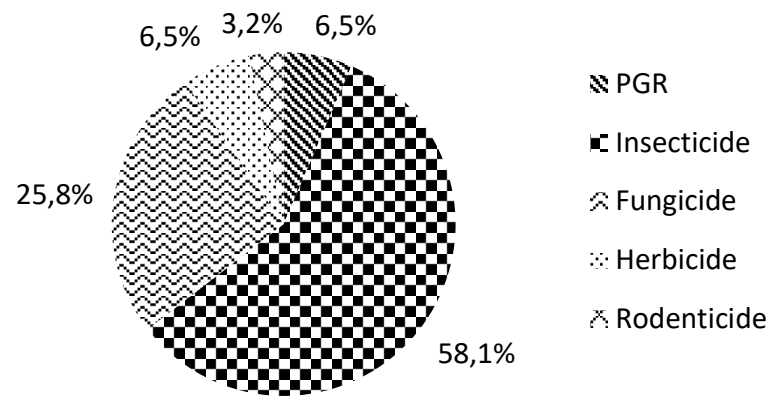

Fig. 1. Distribution of the number of pesticides per pesticide group (source: survey results in the UCRB; private property).

Based on chemical structure and function, the active ingredients (a.i.) were classified into several chemical classes. For insecticide, 18 a.i. in use was divided into 11 chemical classes: Avermectin (Abamectin \& Emamectin Benzoate), Benzoylureas (Lufenuron), Carbamates (Carbofuran, Methomyl, MIPC), Diamonds (Chlorantraniliprole), Neonicotinoids (Imidacloprid), Nereistoxin analogs (Dimehypo), Organochlorine (Endosulfan), Organophosphate (Chlorpyrifos \& Profenofos), Pyrethroids (AlphaCypermethrin, Beta-cyfluthrin, Cypermethrin, Deltamethrin), Pyrrole (Chlorfenapyr), and Spinosyns (Spinetoram).

For fungicide, eight a.i. in use were classified into five chemical groups, i.e., Acylalanines (Mefenoxam), Chloronitriles (Chlorothalonil), Dithio-carbamates (Mancozeb, Maneb, Metiram, Propineb), Methoxy-acrylates (Azoxystrobyn), and Triazoles (Difenoconazole). For herbicide, two a.i. were originated from 2 classes, ie. Bipyridylium (Paraquat dichloride) and Sulfonylurea (Metsulfuron-methyl). The only rodenticide in this survey is part of the group of Hydrocoumarin (Brodifacoum). The last two a.i. of PGR were classified as Sodium nitro compound (2-Nitrophenol Sodium Salt \& 4-Nitrophenol Sodium Salt).

The chemical grouping was based on MoA classification of Insecticide Resistance Action Committee (IRAC; [16]), Fungicide Resistance Action Committee (FRAC; [17]), Herbicide Resistance Action Committee (HRAC; [18]), and Rodenticide Resistance Action Committee (RRAC; [19]). In general, pesticides in the same chemical group usually share a common target site within the pest and have similarity in primary structure, chemical character, and distinctive physiological effect [16].

\subsection{Pesticide occurrence, weight percentage, concentration, and frequency of application}

Farmers from UCRB were interviewed about the concentration or weight percentage of the pesticide, a.i. (taken from the pesticide package label), frequency, and amount of application for each crop. Details from the survey of pesticide use are given in Table 1. 
Table 1. Survey result of pesticide occurrence, weight percentage, the concentration of A.I., and average frequency of pesticide application for each crop type in the UCRB.

\begin{tabular}{|c|c|c|c|c|c|c|}
\hline Crop & Pesticide & $\begin{array}{c}\text { Group } \\
*)\end{array}$ & $\begin{array}{l}\text { Occurrence } \\
\text { (number of } \\
\text { fields) }\end{array}$ & $\begin{array}{l}\text { The weight } \\
\text { percentage } \\
\text { of A.I. }(\%)\end{array}$ & $\begin{array}{c}\text { The } \\
\text { concentration } \\
\text { of A.I. }(\mathrm{g} / \mathrm{l})\end{array}$ & $\begin{array}{c}\text { Average } \\
\text { frequency } \\
\text { (times/ } \\
\text { month) }\end{array}$ \\
\hline \multirow[t]{15}{*}{ Rice } & Alpha-cypermethrin & I & 4 & - & 15 & 0.60 \\
\hline & Beta-cyfluthrin & I & 2 & - & 25 & 0.41 \\
\hline & Brodifacoum & $\mathrm{R}$ & 3 & $0.005 \%$ & - & 0.25 \\
\hline & Carbofuran & I & 34 & $3 \%$ & - & 0.46 \\
\hline & Chlorpyrifos & I & 13 & - & $200-540$ & 0.64 \\
\hline & Cypermethrin & I & 11 & - & $30-100$ & 0.66 \\
\hline & Deltamethrin & I & 32 & - & 25 & 0.57 \\
\hline & Dimehypo & I & 3 & - & 400 & 0.25 \\
\hline & Endosulfan & I & 10 & $35 \%$ & 350 & 0.54 \\
\hline & Imidacloprid & I & 1 & - & 100 & 0.75 \\
\hline & Mancozeb & $\mathrm{F}$ & 1 & $80 \%$ & - & 0.75 \\
\hline & Metsulfuron-methyl & $\mathrm{H}$ & 2 & $0.70 \%$ & - & 0.5 \\
\hline & MIPC (Isoprocarb) & I & 14 & $50 \%$ & - & 0.49 \\
\hline & Profenofos & I & 2 & - & 500 & 0.67 \\
\hline & Propineb & $\mathrm{F}$ & 3 & $70 \%$ & - & 0.83 \\
\hline \multirow[t]{13}{*}{ Chili } & Abamectin & I & 15 & - & $18-18.4$ & 7.2 \\
\hline & Azoxystrobin & $\mathrm{F}$ & 2 & - & 200 & 3.5 \\
\hline & Chlorantraniliprole & I & 2 & - & 50 & 6 \\
\hline & Chlorothalonil & $\mathrm{F}$ & 3 & $75 \%$ & - & 4.67 \\
\hline & Chlorpyrifos & I & 3 & - & 200 & 3.33 \\
\hline & Deltamethrin & I & 4 & - & 25 & 4.5 \\
\hline & Difenoconazole & $\mathrm{F}$ & 4 & - & $125-250$ & 5.25 \\
\hline & Emamectin benzoate & I & 4 & $5.70 \%$ & 22 & 5.5 \\
\hline & Mancozeb & $\mathrm{F}$ & 24 & $64 \%-80 \%$ & - & 5.33 \\
\hline & Maneb & $\mathrm{F}$ & 7 & $80 \%$ & - & 8 \\
\hline & Mefenoxam & $\mathrm{F}$ & 2 & $4 \%$ & - & 2 \\
\hline & Profenofos & I & 26 & - & 500 & 5.77 \\
\hline & Propineb & $\mathrm{F}$ & 3 & $70 \%$ & - & 5.33 \\
\hline \multirow{13}{*}{ Tomato } & Abamectin & I & 7 & - & $18-18.4$ & 8.57 \\
\hline & Chlorantraniliprole & I & 2 & - & 50 & 7.83 \\
\hline & Chlorfenapyr & I & 1 & - & 300 & 1 \\
\hline & Chlorothalonil & $\mathrm{F}$ & 4 & $75 \%$ & - & 7.42 \\
\hline & Deltamethrin & I & 4 & - & 25 & 4.5 \\
\hline & Difenoconazole & $\mathrm{F}$ & 1 & - & 250 & 10 \\
\hline & Emamectin benzoate & I & 2 & - & 22 & 4.5 \\
\hline & Mancozeb & $\mathrm{F}$ & 14 & $80 \%$ & - & 6 \\
\hline & Maneb & $\mathrm{F}$ & 4 & $80 \%$ & - & 9.5 \\
\hline & Metiram & $\mathrm{F}$ & 1 & $70 \%$ & - & 4 \\
\hline & Profenofos & I & 15 & - & 500 & 6.58 \\
\hline & Propineb & $\mathrm{F}$ & 1 & $70 \%$ & - & 4 \\
\hline & Spinetoram & I & 1 & - & 120 & 1 \\
\hline \multirow[t]{11}{*}{ Cabbage } & Abamectin & I & 8 & - & $18-18.4$ & 7.13 \\
\hline & Chlorantraniliprole & I & 4 & - & 50 & 5.75 \\
\hline & Chlorfenapyr & I & 1 & - & 250 & 4 \\
\hline & Chlorothalonil & $\mathrm{F}$ & 4 & $75 \%$ & - & 5.33 \\
\hline & Chlorpyrifos & I & 1 & - & 200 & 8 \\
\hline & Cypermethrin & I & 3 & - & 50 & 5.11 \\
\hline & Difenoconazole & $\mathrm{F}$ & 2 & - & 250 & 10 \\
\hline & Mancozeb & $\mathrm{F}$ & 4 & $80 \%$ & - & 10 \\
\hline & Maneb & $\mathrm{F}$ & 6 & $80 \%$ & - & 9 \\
\hline & Methomyl & I & 1 & $40 \%$ & - & 4 \\
\hline & Profenofos & I & 7 & - & 500 & 8.86 \\
\hline
\end{tabular}


Table 1. (continued).

\begin{tabular}{|c|c|c|c|c|c|c|}
\hline Crop & Pesticide & $\begin{array}{c}\text { Group } \\
*)\end{array}$ & $\begin{array}{c}\text { Occurrence } \\
\text { (number of } \\
\text { fields) }\end{array}$ & $\begin{array}{l}\text { The weight } \\
\text { percentage } \\
\text { of A.I. }(\%)\end{array}$ & $\begin{array}{c}\text { The } \\
\text { concentration } \\
\text { of A.I. }(\mathrm{g} / \mathbf{l})\end{array}$ & $\begin{array}{c}\text { Average } \\
\text { frequency } \\
\text { (times/ } \\
\text { month) }\end{array}$ \\
\hline \multirow[t]{5}{*}{ Coffee } & Chlorpyrifos & I & 2 & - & 200 & 0.42 \\
\hline & Cypermethrin & I & 1 & - & 30.36 & 0.33 \\
\hline & $\begin{array}{l}\text { Paraquat } \\
\text { dichloride }\end{array}$ & $\mathrm{H}$ & 2 & - & 276 & 4 \\
\hline & Profenofos & I & 2 & - & 500 & 0.17 \\
\hline & Propineb & F & 1 & $70 \%$ & - & 0.67 \\
\hline \multirow[t]{6}{*}{ Broccoli } & Abamectin & I & 2 & - & $18-18.4$ & 6.25 \\
\hline & Chlorfenapyr & I & 1 & - & 300 & 4 \\
\hline & Mancozeb & $\mathrm{F}$ & 3 & $80 \%$ & - & 5.33 \\
\hline & Maneb & F & 1 & $80 \%$ & - & 10 \\
\hline & Profenofos & I & 2 & - & 500 & 6 \\
\hline & Propineb & $\mathrm{F}$ & 1 & $70 \%$ & - & 0.5 \\
\hline \multirow[t]{5}{*}{ Corn } & $\begin{array}{l}\text { Alpha- } \\
\text { cypermethrin }\end{array}$ & I & 1 & - & 15 & 0.5 \\
\hline & Carbofuran & I & 1 & $3 \%$ & - & 0.67 \\
\hline & Deltamethrin & I & 2 & - & 25 & 0.42 \\
\hline & Mancozeb & $\mathrm{F}$ & 1 & $80 \%$ & - & 4 \\
\hline & Propineb & F & 1 & $70 \%$ & - & 0.5 \\
\hline \multirow[t]{6}{*}{$\begin{array}{l}\text { Spring } \\
\text { onion }\end{array}$} & $\begin{array}{l}\text { 2-Nitrophenol } \\
\text { sodium salt }\end{array}$ & PGR & 1 & - & 2 & 6 \\
\hline & $\begin{array}{l}\text { 4-Nitrophenol } \\
\text { sodium salt }\end{array}$ & PGR & 1 & - & 3 & 6 \\
\hline & Azoxystrobin & F & 3 & - & 200 & 3.5 \\
\hline & Chlorothalonil & $\mathrm{F}$ & 1 & $75 \%$ & - & 1.5 \\
\hline & Difenoconazole & $\mathrm{F}$ & 3 & - & 125 & 3.5 \\
\hline & Mancozeb & $\mathrm{F}$ & 3 & $80 \%$ & - & 3.5 \\
\hline \multirow{7}{*}{ Strawberry } & Abamectin & I & 1 & - & 18 & 4 \\
\hline & Azoxystrobin & $\mathrm{F}$ & 2 & - & 200 & 4 \\
\hline & Difenoconazole & $\mathrm{F}$ & 2 & - & 125 & 4 \\
\hline & Lufenuron & I & 1 & - & 50 & 0.33 \\
\hline & Mancozeb & $\mathrm{F}$ & 1 & $64 \%-80 \%$ & - & 1 \\
\hline & Mefenoxam & F & 1 & $4 \%$ & - & 1 \\
\hline & Profenofos & I & 3 & - & 500 & 3 \\
\hline \multirow{4}{*}{ Carrot } & $\begin{array}{l}\text { Alpha- } \\
\text { cypermethrin }\end{array}$ & I & 1 & - & 15 & 0.67 \\
\hline & Mancozeb & $\mathrm{F}$ & 3 & $64 \%-80 \%$ & - & 1.33 \\
\hline & Mefenoxam & $\mathrm{F}$ & 1 & $4 \%$ & - & 1 \\
\hline & Profenofos & I & 1 & - & 500 & 1 \\
\hline \multirow{4}{*}{ Potato } & Chlorothalonil & $\mathrm{F}$ & 2 & $75 \%$ & - & 4 \\
\hline & Chlorpyrifos & I & 1 & - & 200 & 1 \\
\hline & Mancozeb & $\mathrm{F}$ & 3 & $80 \%$ & - & 3 \\
\hline & Profenofos & I & 1 & - & 500 & 4 \\
\hline \multirow[t]{5}{*}{ String beans } & Abamectin & I & 2 & - & $18-18.4$ & 10 \\
\hline & Mancozeb & $\mathrm{F}$ & 2 & $80 \%$ & - & 10 \\
\hline & Maneb & $\mathrm{F}$ & 1 & $80 \%$ & - & 10 \\
\hline & Profenofos & I & 2 & - & 500 & 10 \\
\hline & Propineb & $\mathrm{F}$ & 1 & $70 \%$ & - & 1 \\
\hline \multirow{4}{*}{$\begin{array}{l}\text { Cassava } \\
\text { Sweet } \\
\text { potato }\end{array}$} & Deltamethrin & I & 2 & - & 25 & 0.17 \\
\hline & Carbofuran & I & 1 & $3 \%$ & - & 1 \\
\hline & Cypermethrin & I & 1 & - & 30.36 & 1 \\
\hline & Propine & $\mathrm{F}$ & 1 & $70 \%$ & - & 0.67 \\
\hline
\end{tabular}


Table 1. (continued).

\begin{tabular}{|c|c|c|c|c|c|c|}
\hline Crop & Pesticide & $\begin{array}{c}\text { Group } \\
*)\end{array}$ & $\begin{array}{l}\text { Occurrence } \\
\text { (number of } \\
\text { fields) }\end{array}$ & $\begin{array}{l}\text { The weight } \\
\text { percentage } \\
\text { of A.I. }(\%)\end{array}$ & $\begin{array}{c}\text { The } \\
\text { concentration } \\
\text { of A.I. }(g / \mathbf{l})\end{array}$ & $\begin{array}{c}\text { Average } \\
\text { frequency } \\
\text { (times/ } \\
\text { month) }\end{array}$ \\
\hline \multirow[t]{2}{*}{ Chayote } & Chlorpyrifos & I & 1 & - & 200 & 1 \\
\hline & Propine & $\mathrm{F}$ & 1 & $70 \%$ & - & 1 \\
\hline \multirow[t]{2}{*}{ Lettuce } & Chlorfenapyr & I & 1 & - & 300 & 4 \\
\hline & Mancozeb & $\mathrm{F}$ & 1 & $80 \%$ & - & 2 \\
\hline \multirow[t]{3}{*}{ Long bean } & Abamectin & I & 1 & - & 18.4 & 10 \\
\hline & Mancozeb & $\mathrm{F}$ & 1 & $80 \%$ & - & 10 \\
\hline & Profenofos & I & 1 & - & 500 & 10 \\
\hline \multirow[t]{4}{*}{ Cauliflower } & Abamectin & I & 1 & - & 18 & 10 \\
\hline & Mancozeb & $\mathrm{F}$ & 1 & $80 \%$ & - & 10 \\
\hline & Maneb & $\mathrm{F}$ & 1 & $80 \%$ & - & 10 \\
\hline & Profenofos & I & 1 & - & 500 & 10 \\
\hline \multirow[t]{3}{*}{ Eggplant } & Abamectin & I & 1 & - & 18 & 10 \\
\hline & Mancozeb & $\mathrm{F}$ & 1 & $80 \%$ & - & 10 \\
\hline & Profenofos & I & 1 & - & 500 & 10 \\
\hline Bitter gourd & Propineb & $\mathrm{F}$ & 1 & $70 \%$ & - & 0.5 \\
\hline \multirow{2}{*}{ Cucumber } & $\begin{array}{l}\text { Alpha- } \\
\text { cypermethrin }\end{array}$ & I & 1 & - & 15 & 1 \\
\hline & Deltamethrin & I & 1 & - & 25 & 1 \\
\hline
\end{tabular}

*)PGR: Plant Growth Regulator; I: Insecticide; R: Rodenticide; F: Fungicide; H: Herbicide.

For rice crops, from 111 rice fields, we found that Carbamates and Pyrethroid-based insecticides such as Carbofuran and Deltamethrin were the two most frequently used pesticides (34 farmers and 32 farmers, respectively). Carbofuran is one of the most toxic Carbamate pesticides [20], and it controls aphids, stemborers, and golden snails. At the same time, Deltamethrin is used to control insect pests such as cutworm and diamondback moth. The usage of rodenticide and herbicide in rice was relatively small compared to insecticides. Brodifacoum rodenticide is used to control rats, while the herbicide of Metsulfuron-methyl is used to control weeds in the rice field.

Some rice farmers still used Endosulfan to control green and brown leafhoppers. Endosulfan is an organochlorine compound that has been internationally banned by the Stockholm Convention in 2011. Another banned insecticide that was found in the survey was Chlorpyrifos. The use of Chlorpyrifos in Indonesia is generally restricted in agriculture. It was even banned mostly in rice field agriculture [21, 22]. Based on Sousa et al. (2018), some studies reported that Chlorpyrifos and Endosulfan concentrations in most developing Asian countries, for instance, India, exceeded the Environmental Quality Standard (EQS) values. In this study, the usage of both pesticides was relatively lower in UCRB than in other Asia Countries [24]. Despite other pesticides being found at lower levels, their presence is still a concern since the toxicity can be significant, leading to adverse effects on ecosystems or human health even at low concentrations [25].

Vegetable crops such as chili and tomato were mostly treated using Profenofos and Mancozeb. For chili, 26 farmers used Profenofos, and 24 farmers used Mancozeb. For tomato, 15 farmers use Profenofos, and 14 farmers use Mancozeb. Profenofos and Mancozeb, being applied multiple times per month (5-7 times/month), are used to control caterpillars, whiteflies, mealybugs (Profenofos), and to control leaf diseases such as leaf spot and rust (Mancozeb). Pesticides that were used in tomato were similar to pesticides in chili. From the 13 pesticides applied in tomato cropping, ten pesticides were also used in chili cropping: Chlorothalonil, Maneb, Propineb, Mancozeb, Profenofos, Chlorantraniliprol, Emmamectin benzoate, Abamectin, Difenoconazole, and Deltamethrin. The main reason seems that most of the tomato farmers also grew chili in their fields. In total, the most 
comprehensive used pesticide in this questionnaire survey was Profenofos with 64 crops, and Mancozeb came in second place with 63 crops using it.

To determine the average amount of pesticide used, we also needed the concentration or weight percentage of a.i. Per pesticide. The survey result showed that each pesticide had a different concentration or weight percentage of a.i. based on the brand used. Pesticide in liquid form with the highest concentration of its a.i. was Profenofos, with a concentration of $500 \mathrm{~g} / \mathrm{l}$. The lowest concentration was 2-Nitrophenol Sodium Salt with a concentration of 2 g/l. A.i.'s of pesticides in solid form was expressed with weight percentage. The highest weight percentage was Mancozeb and Maneb, with a percentage of $80 \%$, and the lowest was Brodifacoum, with a weight percentage of $0.005 \%$. These differences made every a.i. of pesticide had a different dosage of application.

Another critical parameter to determine the average amount of pesticide a.i. of each crop in UCRB was applying every farmer habit and crop. Based on the interviews, farmers in UCRB seemed to have their dosage or recipes of mixed pesticides and based the croptype specific application frequency on their experience rather than the prescribed frequency. Almost all of them mixed one pesticide to another except in the case of cassava and bitter gourd. See Fig. 2 for the frequency of pesticide application.

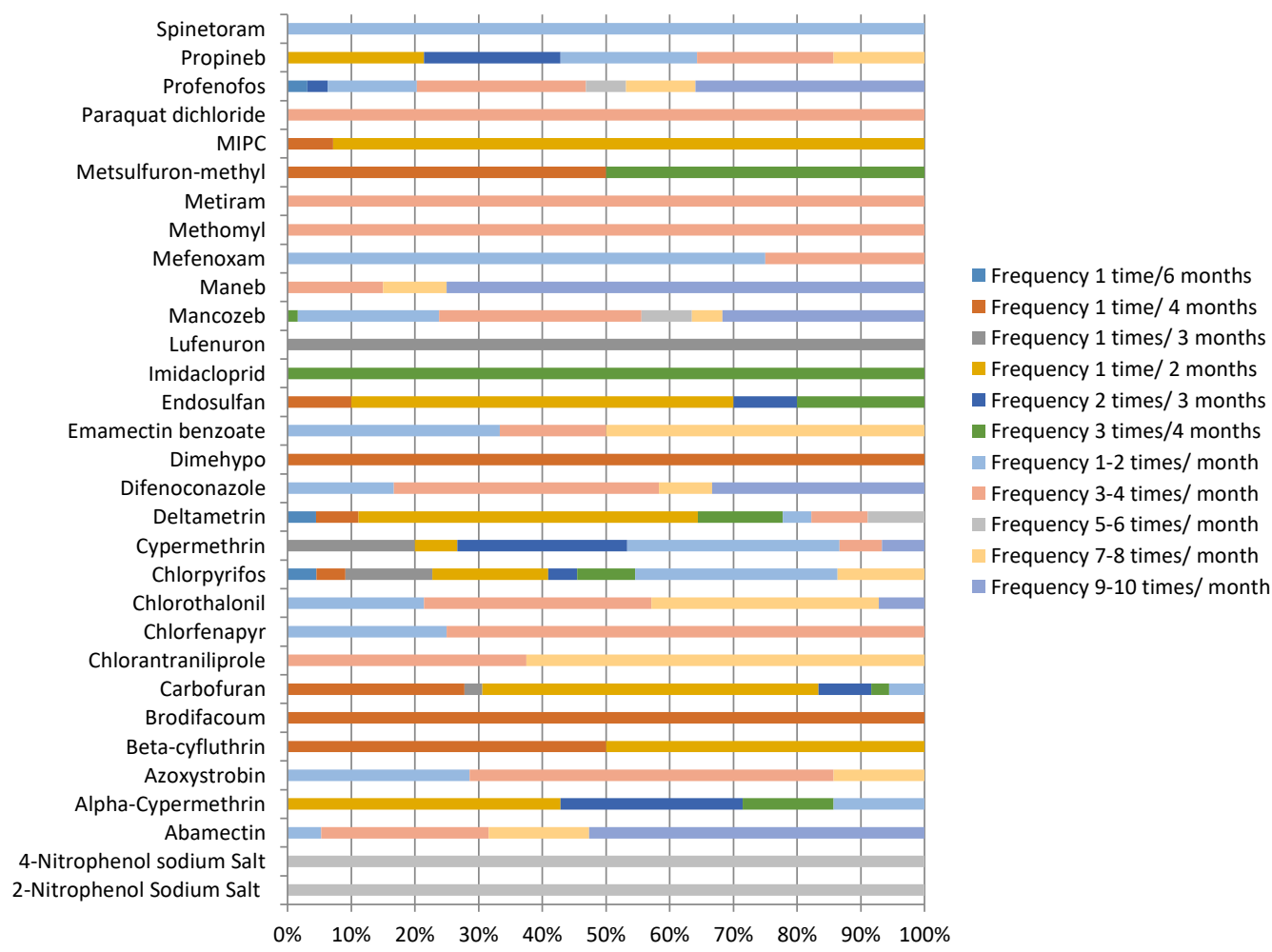

Fig. 2. Distribution of application frequency for pesticides used by surveyed farmers in the UCRB (source: survey results in the UCRB; private property).

From Fig. 2, we can see the various application frequencies ranging from 1 time per 6 months to 9-10 times per month. The frequency of application depends on the crop type, as we can see in Table 1. For rice, pesticide application is mostly less than one time per month or once to three times per growing season. In comparison, vegetables such as string bean, 
long bean, cauliflower, and eggplant had a high frequency of pesticide spraying up until 910 times/ month. The variation in pesticide application frequency influenced the amount of the pesticide used for each crop.

In general, we noted that the frequency of pesticide application to vegetables was higher (from 7-10 times/ month), while rice and tubers' frequency was lower (1-3 times/growing season). The other factor influencing the average usage is the dosage of the pesticide per application. Many farmers included in the survey did not follow the recommended dose and rate of application on the package label, i.e. the amount of formulation per pesticide mixture or number of tablespoons of formulated product per spray load. They used their own recipes on their pesticide mixture based on their habits, experiences, or other farmers' suggestions. Thrveyed results showed that information about the dosage of pesticide and its application was specific to the crop types and relative to the farmers and their farm size.

\section{Conclusions}

The questionnaire result showed that 31 pesticides were in use by farmers in the UCRB, consisting of $58 \%$ of insecticides, $26 \%$ of fungicides, $7 \%$ of herbicides, $3 \%$ rodenticides, and $7 \%$ PGR. The survey result showed that Profenofos and Mancozeb had the most extensive pesticide use in UCRB. In rice crop, Carbamates and Pyrethroid-based insecticides such as Carbofuran and Deltamethrin were the two most frequently mentioned pesticides by the majority of the farmers. The variation of pesticide application frequency influenced the amount of the pesticide applied for each crop. For rice, pesticide applications mostly less than one time per month or once to three times application per growing season. The average frequency of pesticide application in vegetables was higher than rice crop with the frequency of spraying from 7-10 times/ month.

This study provides valuable data on pesticide use, e.g., estimating emissions, and subsequently, the concentrations in surface water in the UCRB [26]. These concentrations can be used to estimate toxic effects on species and humans to inform policy and management. The survey serves as a starting point for investigating pesticide use in an agricultural region with minimal data on pesticide usage. At the same time, pesticide residue analyses can be very costly and time-consuming. This study might be useful to develop the monitoring program of the water samples to target specific chemicals for analysis.

\section{Acknowledgements}

The authors want to acknowledge the Radboud University and Deltares for their financial support. The authors would also like to thank Ibu Iwa Kustiwa and Bapak Deni Riswandani (ELINGAN) for assisting during the survey.

\section{References}

1. C.A. Damalas and I.G. Eleftherohorinos, Int. J. Environ. Res. Publ. Health 8, 1402 (2011)

2. P.J.P. Verger and A.R. Boobis, Science 341,717-718 (2013)

3. A. Masiá, C. Blasco, Y. Picó, Trends Environ. Anal. Chem. 2, 11-24 (2014)

4. V. Silva, H.G.J. Mol, P. Zomer, M. Tienstra, C.J. Ritsema, V. Geissena, Sci. Total Environ. 653, 1532-1545 (2019) 
5. M. Akter, L. Fan, M.M. Rahman, V. Geissen, C.J. Ritsema, J. Clean. Prod. 200, 122133 (2018)

6. J.E. Balmer, A.D. Morris, H. Hung, L. Jantunen, K. Vorkamp, F. Rigét, M. Evans, M. Houde, D.C.G. Muir, Emerg. Contam. 5, 70-88 (2019)

7. A. Tsaboula, E.N. Papadakis, Z. Vryzas, A. Kotopoulou, K. Kintzikoglou, E. Papadopoulou- Mourkidou, Environ. Int. 91, 78-93 (2016)

8. M. Kapsi, C. Tsoutsi, A. Paschalidou, T. Albanis, Sci. Total Environ. 650, 2188-2198 (2019)

9. E. Herrero-Hernández, M.S. Rodríguez-Cruz, E. Pose-Juan, S. Sánchez-González, M.S. Andrades, M.J. Sánchez-Martín, Sci. Total Environ. 609, 161-171 (2017)

10. T.F. Bidleman, A.D. Leone, R.L. Falconer, T. Harner, L.M.M. Jantunen, K. Wiberg, P.A. Helm, M.L. Diamond, B. Loo, Sci. World J. 2, 357 - 373 (2002)

11. I.K. Konstantinou, D.G. Hela, T.A. Albanis, Environ. Pollut. 141, 555-570 (2006)

12. O.S.A. Al-Khazrajy and A.B.A. Boxall, Environ. Sci. Pollut. Res. 23, 15712-15726 (2016)

13. J. Van Gils, L. Posthuma, I.T. Cousins, C. Lindim, D. de Zwart, D. Bunke, S. Kutsarova, C. Müller, J, Munthe, J. Slobodnik, W. Brack, Environ. Sci. Eur. 31 (1), 72 (2019)

14. N. Berenzen, A. Lentzen-Godding, M. Probst, H. Schulz, R. Schulz, S. Liess, Chemosphere 58, 683-691 (2005)

15. E.E. Burns, L.J. Carter, J. Snape, J. Thomas-Oates, A.B.A. Boxall, J. Toxicol. Environ. Health B Crit. Rev. 21:3, 115-141 (2018)

16. Insecticide Resistance Action Committee (IRAC), IRAC Mode of Action Classification Scheme, Version 9.3. (2019)

17. Fungicide Resistance Action Committee (FRAC), FRAC Code List (C)2019: Fungicides sorted by mode of action (including FRAC Code numbering) (2019)

18. Herbicide Resistance Action Committee (HRAC), Infographic: The World of Herbicides, According to HRAC Classification on the mode of action 2010 (2010)

19. Rodenticide Resistance Action Committee (RRAC), RRAC guidelines on Anticoagulant Rodenticide Resistance Management (2015)

20. L. Fabro and L.M. Varca, Agric. Water Manag. 106, 27- 34 (2012)

21. Ministry of Agriculture Republic of Indonesia, Ministerial Regulation of Agriculture, No.: 24/Permentan/SR.140/4/2011 about Requirements and Procedures of Pesticide Registration (in Bahasa, 2011)

22. Ministry of Agriculture Republic of Indonesia, Ministerial Regulation of Agriculture, No.: 39/Permentan/SR.330/7/2015 about Pesticide Registration (in Bahasa, 2015)

23. J.C.G. Sousa, A.R. Ribeiro, M.O. Barbosa, M.F.R Pereira, A.M.T. Silva, J. Hazard. Mater. 344, 146-162 (2018)

24. Phillips McDouglas Agribusiness Intelligence, Infographic: Key Performance Trends in the Global Crop Protection Industry in 2018 (2019)

25. Z.R. Hopkins and L. Blaney L, Environ. Int. 92-93, 301-316 (2016)

26. R.R. Utami, G.W. Geerling, I.R.S. Salami, S. Notodarmojo, A.M.J. Ragas, Sci. Total Environ. 738, 140130 (2020) 